\title{
Changes in the oxidative status of dual-purpose hens rearing in the free-range system during cold, thermoneutral and hot period
}

\section{Vasko Gerzilov ( $\sim$ v_gerzilov@abv.bg )}

Agricultural University https://orcid.org/0000-0001-7537-3811

Albena Alexandrova

Bulgarian Academy of Sciences: B'Igarska akademia na naukite

Almira Georgieva

Bulgarian Academy of Sciences: B'Igarska akademia na naukite

\section{Elina Tzvetanova}

Bulgarian Academy of Sciences: B'Igarska akademia na naukite

Neli Keranova

Agricultural University Plovdiv: Agraren universitet Plovdiv

Veselina Boncheva

Agricultural University Plovdiv: Agraren universitet Plovdiv

Petar Petrov

Agricultural University Plovdiv: Agraren universitet Plovdiv

\section{Research Article}

Keywords: Antioxidant enzymes, Chicken genotype, Cold and hot periods, Oxidative status, Egg production

Posted Date: January 27th, 2022

DOl: https://doi.org/10.21203/rs.3.rs-1260995/v1

License: () (i) This work is licensed under a Creative Commons Attribution 4.0 International License. Read Full License 


\section{Abstract}

This trial studied the influence of environmental conditions (cold, thermoneutral and hot period) on oxidative status of different genotypes free-range laying hens and the effect of oxidative stress (OS) on their egg productive performance. In the experiment, carried with a two-year replication, were used six dual-purpose chicken genotypes with different origins. For determination of the oxidative status were measured the levels of lipid peroxidation (LPO), total glutathione (tGSH) and the activity of antioxidant enzymes catalase (CAT), superoxide dismutase (SOD), and glutathione peroxidase (GPX). The highest egg production for all chicken genotypes was reported during the thermoneutral period. Biochemical parameters LPO and CAT were relatively more sensitive to environmental impact while the remaining ( $\mathrm{tGSH}, \mathrm{SOD}, \mathrm{GPX}$ ) exhibited a higher degree of stability. The lowest values of LPO for all genotypes were proved during the thermoneutral period. The cold period was most unfavorable - LPO values are elevated for all genotypes. The SOD and GPX values were higher during the cold and the hot periods compared to the thermoneutral. The results of analysis of variance showed that the factor "temperature period" compared to "year" and "genotype" had the most significant influence on all biochemical parameters $(P<0.001)$. Significant phenotypic correlations $(P<0.05)$ were detected among all biochemical parameters, except for correlation between SOD and $t G S H$. The chicken genotypes showed differences in their susceptibility to OS. Thermal stress (either cold or heat) affected adversely the oxidative status of hens because it induces OS and can play a significant role in determining chicken welfare and egg production.

\section{Introduction}

As a result of consumers' changing perception of animal production systems, there has been an increased interest in free-range poultry production. It is believed that free-range birds have specific advantages such as direct contact with sun rays and fresh air, opportunity to perform their natural behavioural instincts (rooting, dust bathing), pecking grains or pebbles (Henry 2002). On the other hand, a higher risk of stress exists in free-farming rearing systems, associated with factors as changing environmental conditions, parasitic, bacterial and viral infections (Fossum et al. 2009; Wuthijaree et al. 2017), contamination, aggression from dominant birds, pecking and risk of cannibalism (Appleby and Hughes 1991; Lambton et al. 2015) etc. especially, ambient temperature is being widely recognized as a main stress factor (Lin et al. 2006; Singh et al. 2017; Vandana et al. 2021). It seems highly realistic that free-range farming may also face problems associated with local manifestations of climate change, especially the extension of the warm period not only in geographic areas affected by high environmental temperatures but also in Europe (Alexandrov et al. 2002; Lamarca et al. 2018).

Stress is a response of a body to adverse stimuli, which is nonspecific and any agent that induces stress is defined as a stressor (Selye 1976). Therefore, any type of stress exhibits a biological response or reaction to stimuli that adversely affect normal physiological homeostasis. OS can be triggered by a number of factors as a reaction to their impact. OS is a condition characterized by an imbalance between the pro-oxidant processes, induced by the reactive oxygen species (ROS), and the antioxidant defence in organisms (Sies 1985). ROS are highly reactive and can threat the cellular constituents, leading ultimately to cell death. Because ROS are normally generated in the organism, a defence system (including enzyme and non-enzyme antioxidants) was developed evolutionary in order to neutralize their harmful effects. However, upon different environmental stressors (as extreme temperatures, contamination, UV radiation, pathogens, etc.) excess production of ROS is provoked that exceeds the defence mechanisms capacity and OS can occur. Mild stress serves as a signal to activate signalling pathways important to overcome the effects of negative factors and to ensure normal physiological functions. Severe stress, however, leads to cell structure damage and cell death.

In controlled trials, the chronic or acute exposure of birds to high or low temperatures increased lipid peroxidation (LPO) levels, as a marker of OS, and changes in the activity of antioxidant enzymes were established (Lin et al. 2006; Akşit et al. 2008; Ming et al. 2012; Zhao et al. 2014). In turn, increased LPO can have a significant negative impact on the well-being of the birds and, accordingly, on the quantity and quality of the expected products (Rhoads et al. 2013).

The conventional cage systems for laying hens have been banned, at least in the European Union (EU Council Directive 1999) and more farms turn towards free-range rearing systems. At the same time, relatively few studies exist on the possible effects of free-range rearing on the oxidative status of birds and their performance. Although the interest in free-range farming is rising, 
there is still relatively little research concerning the adaptability of the used chicken genotypes to variations in environmental factors during the free-range rearing and impacts on the hen's productivity. As far as different rearing conditions are known to cause different stress an interesting question arises, whether different genotypes of free-range birds are differently susceptible to OS and how this can affect egg production. Some studies suggest that different genotypes of hens may be differentially sensitive to OS and this may affect their liveability and performance (Küçükyılmaz et al. 2012; Mack et al. 2013).

Given the ability of OS to direct the cellular response in different directions and the genetic predisposition of the functional qualities of organisms, we hypothesize that shifts in the pro/antioxidant balance in chickens may depend more strongly, than previously known, on the genotype of the birds which can be manifested on the physiological level by significant changes in their performance in response to rearing conditions. Thus, the aim of the present study was to assess the changes in the oxidative status of different hen's genotypes in response to the conditions of environmental in a free-range rearing system and the possible effects on egg production performance. The changes in oxidation status were reported by measuring the levels of the following biochemical parameters: LPO, tGSH, CAT, SOD, and GPX in erythrocyte suspension.

\section{Materials And Methods Birds and housing}

In the present study six well-known genotypes of dual-purpose chickens were used which were reared under a free-range system (Fig. 1). Tetra $\mathrm{H}$ and Tetra Super Harco are hybrid combinations produced by Bábolna Tetra Kft. (Hungary) for industrial laying purposes. White Plymouth Rock (line G) and Barred Plymouth Rock (line E) are lines from the National Gene Pool of Bulgaria, which together with the Australorp (from Australia) are well known and widespread breeds that are very popular in small farms due to their high egg yield. The Bielefelder is a relatively new breed originating from Germany.

Chickens were divided into groups according to their genotype, each including 27 hens and 3 cocks, and were reared from 19 to 52 weeks of age. The experiment was carried out in two consecutive years. All groups were reared under the same conditions during the experiment: in a sleeping pen (size 3.50/2.50/2.75 m) with pop-holes and free access to an outdoor walking yard (size $9.20 / 24 \mathrm{~m}$ ) in the poultry division of the Agricultural University of Plovdiv (latitude $42^{\circ} 14^{\prime} \mathrm{N}$, longitude $24^{\circ} 79^{\prime} \mathrm{E}$, and altitude of $164 \mathrm{~m}$ above sea level).

Feed (mash form) and water were offered for consumption ad libitum. The diets were with equal feed and nutrient composition for all groups and were consistent with the laying phase - Table 1.

Table 1 Ingredients and nutrient composition of the diets 


\begin{tabular}{|c|c|c|c|c|}
\hline \multirow[t]{2}{*}{ Components } & \multicolumn{4}{|c|}{ Laying period in week } \\
\hline & $19-20$ & $21-28$ & $29-40$ & $41-52$ \\
\hline \multicolumn{5}{|l|}{ Feed ingredients, g/kg } \\
\hline Corn yellow & 336.7 & 308.2 & 308.2 & 320.0 \\
\hline Wheat & 336.7 & 32.8 .2 & 308.2 & 320.8 \\
\hline Soybeans toasted (440 g crude protein) & 120.0 & 125.0 & 120.0 & 100.0 \\
\hline Sunflower expeller (340 g crude protein) & 150.0 & 150.0 & 150.0 & 150.0 \\
\hline Sunflower oil & - & 12.0 & 50.0 & - \\
\hline L-lysine & 1.1 & 0.7 & 0.1 & 0.5 \\
\hline DL-Methionine & 0.7 & 0.9 & 0.7 & 0.7 \\
\hline Sodium chloride & 2.6 & 2.8 & 2.3 & 2.0 \\
\hline Limestone & 38.0 & 82.0 & 97.0 & 100.0 \\
\hline Dicalcium phosphate & 12.0 & 7.0 & 5.3 & 3.8 \\
\hline Premix TB 301 Layers* & 2.0 & 2.0 & 2.0 & 2.0 \\
\hline Synergen** & 0.2 & 0.2 & 0.2 & 0.2 \\
\hline \multicolumn{5}{|l|}{ Calculated composition (per kg) } \\
\hline Metabolizable energy, MJ/kg & 12.1 & 11.8 & 11.5 & 11.5 \\
\hline Crude protein, $\mathrm{g}$ & 178.0 & 174.0 & 171.0 & 165.0 \\
\hline Crude fiber, g & 45.0 & 44.0 & 44.0 & 43.0 \\
\hline Crude fats, g & 41.0 & 51.0 & 44.0 & 40.0 \\
\hline Calcium, g & 20.0 & 36.0 & 38.1 & 39.2 \\
\hline Phosphorus available, g & 6.6 & 5.6 & 5.3 & 3.0 \\
\hline Lysine, g & 8.5 & 8.1 & 7.5 & 7.3 \\
\hline Methionine+cysteine, g & 7.3 & 7.3 & 7.0 & 6.9 \\
\hline \multicolumn{5}{|c|}{ 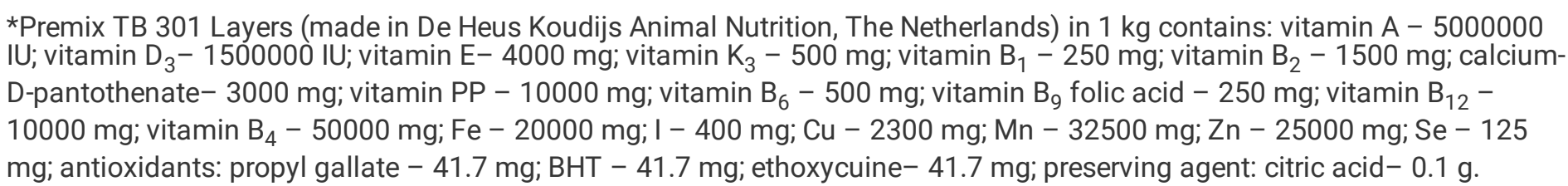 } \\
\hline
\end{tabular}

\section{Experimental design}

Two identical experiments were performed in two consecutive years. The changes in the oxidative status of the hens from the studied six genotypes were evaluated in erythrocyte suspensions. Blood samples $(n=6)$ from each group of laying hens were taken during three thermal periods: cold, neutral and hot in the 1st and 2nd experimental years when the birds were at the 36th, 44th and 52nd weeks, respectively.

- the cold period (36-week-old hens, the month of March; I experiment - weekly average ambient temperature $-4.82^{\circ} \mathrm{C}$; $\min \mathrm{t}-$ $-1.0^{\circ} \mathrm{C}$; max $\mathrm{t}-21.0^{\circ} \mathrm{C}$; Il experiment - weekly average ambient temperature $-6.39^{\circ} \mathrm{C}$; $\min \mathrm{t}--2.8^{\circ} \mathrm{C}$; $\max \mathrm{t}-18.0^{\circ} \mathrm{C}$; 
- the thermoneutral period (44-week-old hens, the month of May; I experiment - weekly average ambient temperature $17.35^{\circ} \mathrm{C}$; $\min \mathrm{t}-8.8^{\circ} \mathrm{C}$; $\max \mathrm{t}-27.4^{\circ} \mathrm{C}$; Il experiment - weekly average ambient temperature $-17.24^{\circ} \mathrm{C} ; \min \mathrm{t}-8.2^{\circ} \mathrm{C}$; $\max \mathrm{t}-$ $\left.26.0^{\circ} \mathrm{C}\right)$;

- the hot period (52-week-old hens, the month of July; I experiment - weekly average ambient temperature $-21.2^{\circ} \mathrm{C}$; $\min \mathrm{t}-$ $13.9^{\circ} \mathrm{C}$; $\max \mathrm{t}-34.5^{\circ} \mathrm{C}$; Il experiment - weekly average ambient temperature $-25.6^{\circ} \mathrm{C}$; $\min \mathrm{t}-16.0^{\circ} \mathrm{C}$; $\max \mathrm{t}-35.8^{\circ} \mathrm{C}$ ).

Egg production was monitored from the age at first egg to 52 weeks of age (in \% weekly). The eggs were collected daily and the total number recorded with respect to the group. Hen-week egg production (\%) was determined as total number of eggs produced by a flock per week $x 100 /$ total number of hens housed $x$.

Meteorological data were taken from the Agro-meteorology station (Plovdiv) at the National Institute of Meteorology and Hydrology, located next to the Poultry division.

\section{Blood collection and preparation of erythrocyte suspension}

The blood of the birds was taken from the $v$. subcuttanea ulnaris in vacutainers (Vacutainer® Plus), as the duration of the manipulation not exceeded 2 minutes.

The blood was centrifuged at $600 \times \mathrm{g}$ for $10 \mathrm{~min}$ at $4^{\circ} \mathrm{C}$. The plasma was removed from the red blood cells and the latter were washed twice with physiological saline under the same conditions. The obtained erythrocyte suspension was frozen and stored at $-80^{\circ} \mathrm{C}$ until analysis.

Erythrocytes as a $5 \%$ suspension (diluted according to $\mathrm{Hb}$ concentration in $0.15 \mathrm{M} \mathrm{NaCl}-10 \mathrm{mM}$ sodium phosphate buffer, $\mathrm{pH}$ 7.2) was used for measurement of the level of lipid peroxidation, total glutathione and the activity of antioxidant enzymes: catalase, superoxide dismutase and glutathione peroxidase.

\section{Biochemical analysis}

Hemoglobin $(\mathrm{Hb})$ amount in erythrocyte suspension was determined spectrophotometrically, using Drabkin's Reagent. Ten $\mu$ l $5 \%$ erythrocyte suspension was added into Drabkin reagent (total volume $1 \mathrm{ml}$ ) and after $20 \mathrm{~min}$ incubation at room temperature the absorbance at $540 \mathrm{~nm}$ was read against Drabkin reagent. The total haemoglobin concentration $(\mathrm{g} / \mathrm{l})$ was determined using a calibration curve.

The levels of LPO, tGSH and the activities of the antioxidant enzymes SOD, CAT and GPX were determined spectrophotometrically using commercially available kits purchased from Sigma-Aldrich Co. LLC (USA): Lipid peroxidation (MDA) Assay Kit MAK085, Glutathione Assay Kit CS0260, SOD Assay Kit-WST 19160, Catalase Assay Kit CAT100, Glutathione Peroxidase Cellular Activity Assay CGP1 (Supplementary material S2).

\section{Statistical analysis}

Data of the OS markers and the rearing conditions factors, and effects on egg performance were subjected to statistical analysis by the Generalized Linear Model Procedure of SPSS 24 statistical environment. The applied analysis of variance (ANOVA) and the calculated F-values and P-values give information about the presence or the absence of statistically proven influence of the respective factors on the values of the studied indicators at the indicated levels of significance.

A comparative assessment of chicken genotypes for the respective period and year of research on the five biochemical parameters was performed by applying post-hoc analysis and the Tukey's test. It provides information on the presence or absence of statistically proven differences between the individual averages for each indicator.

The analysis of variance (ANOVA) and the correlation analysis were performed in the IBM Statistics SPSS 24 statistical environment (Meyers et al. 2013; Hilton and McMurray 2017).

Mean separation was effected using the least significant difference (LSD) and Tukey's multiple range test and tested at $P<0.05$; $P<0.01 ; P<0.001$. 
The statistical model employed was:

$W_{i j k}=\mu+Y_{i}+P_{j}+G_{k}+Y_{i \times} P_{j}+Y_{i \times} G_{k}+P_{j \times} G_{k}+Y_{i \times} P_{j \times} G_{k}+\varepsilon_{i j k}$

where:

$\mathrm{W}_{\mathrm{ijk}}$ - individual observation;

$\mu$ - population mean;

$Y_{i}-$ effect of $i^{\text {th }}$ year ( $i=2$; first and second year);

$P_{j}$ - effect of $j^{\text {th }}$ period $(j=3$; cold, thermoneutral and hot periods $)$

$\mathrm{G}_{\mathrm{k}}$ - effect of $\mathrm{k}^{\text {th }}$ genotype $(\mathrm{k}=6$; Tetra H, Tetra Super Harco, White Plymouth rock, Barred Plymouth rock, Bielefelder, Australorp breeds)

$Y_{i \times} P_{j}$ - effect of the interaction of $i^{\text {th }}$ year and $j^{\text {th }}$ period

$Y_{i \times} G_{k}-$ effect of the interaction of $i^{\text {th }}$ year and $k^{\text {th }}$ genotype

$P j \times G k$ - effect of the interaction of $j^{\text {th }}$ period and $k^{\text {th }}$ genotype

$Y_{i \times} P_{j \times} G_{k}$ - effect of the interaction of $i^{t^{\text {th }}}$ year, $j^{\text {th }}$ period and $k^{\text {th }}$ genotype

$\varepsilon_{\mathrm{ijk}}$ - random residual error normally and independently distributed with zero mean and common variance.

\section{Results}

The results of the experimentally assayed OS markers in the hens from the studied genotypes reared in the free-range system are presented in Table 2. The data obtained showed high variability in the level of the different markers. 
Table 2

Markers of oxidative stress in six chicken genotypes multifactor analysis of variance and Tukey's test *

\begin{tabular}{|c|c|c|c|c|c|c|c|c|c|c|c|c|}
\hline \multicolumn{3}{|c|}{ Factors } & \multicolumn{10}{|c|}{ Biochemical indicators of oxidative stress } \\
\hline \multirow{3}{*}{$\begin{array}{l}\text { Year } \\
\text { I }\end{array}$} & \multirow{3}{*}{$\begin{array}{l}\text { Period } \\
\text { cold }\end{array}$} & \multirow{3}{*}{$\begin{array}{l}\text { Genotype } \\
\text { Tetra H }\end{array}$} & \multirow{2}{*}{\multicolumn{2}{|c|}{$\begin{array}{l}\text { LPO, mol } \\
\mathrm{MDA} / \mathrm{mg} \mathrm{Hb}\end{array}$}} & \multirow{2}{*}{\multicolumn{2}{|c|}{$\begin{array}{l}\text { tGSH } \\
\mathrm{ng} / \mathrm{mg} \mathrm{Hb}\end{array}$}} & \multirow{2}{*}{\multicolumn{2}{|c|}{$\begin{array}{l}\text { CAT } \\
\mathrm{U} / \mathrm{mg} \mathrm{Hb}\end{array}$}} & \multirow{2}{*}{\multicolumn{2}{|c|}{$\begin{array}{l}\text { SOD } \\
\mathrm{U} / \mathrm{mg} \mathrm{Hb}\end{array}$}} & \multirow{2}{*}{\multicolumn{2}{|c|}{$\begin{array}{l}\text { GPX } \\
\mathrm{U} / \mathrm{mg} \mathrm{Hb}\end{array}$}} \\
\hline & & & & & & & & & & & & \\
\hline & & & 1.28 & $a b c$ & 738 & cdefghi & 0.29 & ij & 3.29 & cdef & 38.45 & abcdefg \\
\hline & & $\begin{array}{l}\text { Tetra } \\
\text { Super } \\
\text { Harco }\end{array}$ & 1.81 & $a b$ & 601 & fghi & 0.37 & ghij & 2.61 & defghi & 41.36 & abcd \\
\hline & & $\begin{array}{l}\text { White } \\
\text { Plymouth } \\
\text { rock }\end{array}$ & 1.56 & $a b$ & 642 & efghi & 0.44 & ghij & 1.92 & efghi & 42.00 & abcd \\
\hline & & $\begin{array}{l}\text { Barred } \\
\text { Plymouth } \\
\text { rock }\end{array}$ & 1.21 & abcde & 528 & hi & 0.23 & j & 2.74 & defghi & 28.37 & fghijk \\
\hline & & Bielefelder & 1.24 & abcd & 585 & ghi & 0.41 & ghij & 3.23 & cdefg & 43.83 & $a b c$ \\
\hline & & Australorp & 1.05 & abcde & 490 & $\mathrm{i}$ & 0.46 & fghij & 2.73 & defghi & 50.25 & a \\
\hline & & $\mathrm{m} \pm \mathrm{SEM}$ & 1.36 & & $597 \pm$ & & 0.37 & .04 & $2.75 \pm$ & .20 & $40.71 \pm$ & .94 \\
\hline & thermoneutral & Tetra H & 0.29 & cde & 897 & abcdefghi & 0.30 & hij & 1.55 & $\mathrm{i}$ & 31.75 & cdefghij \\
\hline & & $\begin{array}{l}\text { Tetra } \\
\text { Super } \\
\text { Harco }\end{array}$ & 0.24 & cde & 793 & bcdefghi & 0.45 & ghij & 1.35 & $\mathrm{i}$ & 16.75 & $\mathrm{kl}$ \\
\hline & & $\begin{array}{l}\text { White } \\
\text { Plymouth } \\
\text { rock }\end{array}$ & 0.39 & cde & 828 & bcdefghi & 0.66 & cdefghij & 1.65 & hi & 27.50 & ghijk \\
\hline & & $\begin{array}{l}\text { Barred } \\
\text { Plymouth } \\
\text { rock }\end{array}$ & 0.19 & de & 781 & bcdefghi & 0.57 & defghij & 1.46 & $\mathrm{i}$ & 27.75 & ghijk \\
\hline & & Bielefelder & 0.25 & cde & 817 & bcdefghi & 0.54 & defghij & 1.47 & $\mathrm{i}$ & 34.25 & cdefghi \\
\hline & & Australorp & 0.16 & e & 804 & bcdefghi & 0.57 & defghij & 1.70 & ghi & 40.25 & abcdef \\
\hline & & $\mathrm{m} \pm \mathrm{SEM}$ & 0.26 & & $820 . \pm$ & & $0.52=$ & .05 & $1.53 \pm$ & .05 & $29.71 \pm$ & .23 \\
\hline & hot & Tetra H & 1.77 & $a b$ & 847 & abcdefghi & 1.32 & $a b$ & 5.51 & a & 48.75 & $a b$ \\
\hline & & $\begin{array}{l}\text { Tetra } \\
\text { Super } \\
\text { Harco }\end{array}$ & 1.30 & $a b c$ & 1082 & abcde & 1.54 & a & 4.87 & $a b$ & 31.75 & cdefghij \\
\hline & & $\begin{array}{l}\text { White } \\
\text { Plymouth } \\
\text { rock }\end{array}$ & 1.91 & $a b$ & 853 & abcdefghi & 0.78 & cdefgh & 3.17 & cdefgh & 34.76 & cdefghi \\
\hline & & $\begin{array}{l}\text { Barred } \\
\text { Plymouth } \\
\text { rock }\end{array}$ & 1.91 & $a b$ & 1198 & $a b$ & 0.95 & bcde & 2.71 & defghi & 36.50 & cdefgh \\
\hline & & Bielefelder & 1.01 & abcde & 773 & bcdefghi & 0.58 & defghij & 4.67 & $a b c$ & 31.75 & cdefghij \\
\hline
\end{tabular}

*Note: Values with different letters are significantly different according to ANOVA and Tukey's multiple range test.

If the letter(s) occupy a more forehead position in the alphabet. then the corresponding indicator has a higher value. The presence of identical letters between two indicators means that there is no significant difference. 


\begin{tabular}{|c|c|c|c|c|c|c|c|c|c|c|c|c|}
\hline \multicolumn{3}{|c|}{ Factors } & \multicolumn{10}{|c|}{ Biochemical indicators of oxidative stress } \\
\hline & & Australorp & 0.22 & de & 1105 & abcd & 1.01 & bcd & 3.37 & bcde & 28.55 & fghijk \\
\hline & & $\mathrm{m} \pm \mathrm{SEM}$ & \multicolumn{2}{|c|}{$1.35 \pm 0.27$} & \multicolumn{2}{|c|}{$976 \pm 71$} & \multicolumn{2}{|c|}{$1.03 \pm 0.14$} & \multicolumn{2}{|c|}{$4.05 \pm 0.46$} & \multicolumn{2}{|c|}{$35.34 \pm 2.91$} \\
\hline \multirow[t]{20}{*}{ II } & \multirow[t]{7}{*}{ cold } & Tetra $\mathrm{H}$ & 1.16 & abcde & 597 & fghi & 0.53 & defghij & 3.17 & cdefgh & 35.30 & cdefghi \\
\hline & & $\begin{array}{l}\text { Tetra } \\
\text { Super } \\
\text { Harco }\end{array}$ & 1.98 & a & 704 & defghi & 0.39 & ghij & 2.54 & defghi & 32.97 & cdefghij \\
\hline & & $\begin{array}{l}\text { White } \\
\text { Plymouth } \\
\text { rock }\end{array}$ & 1.29 & $a b c$ & 1042 & abcdef & 0.40 & ghij & 2.60 & defghi & 33.67 & cdefghi \\
\hline & & $\begin{array}{l}\text { Barred } \\
\text { Plymouth } \\
\text { rock }\end{array}$ & 1.55 & $a b$ & 742 & cdefghi & 0.26 & ij & 2.39 & defghi & 34.58 & cdefghi \\
\hline & & Bielefelder & 0.44 & cde & 658 & defghi & 0.43 & ghij & 2.39 & defghi & 36.96 & bcdefgh \\
\hline & & Australorp & 1.02 & & 888 & abcdefghi & 0.74 & cdefghi & 2.45 & defghi & 40.96 & abcde \\
\hline & & $\mathrm{m} \pm \mathrm{SEM}$ & \multicolumn{2}{|c|}{$1.24 \pm 0.21$} & \multicolumn{2}{|c|}{$772 \pm 67$} & \multicolumn{2}{|c|}{$0.46 \pm 0.07$} & \multicolumn{2}{|c|}{$2.59 \pm 0.12$} & \multicolumn{2}{|c|}{$35.74 \pm 1.19$} \\
\hline & \multirow[t]{7}{*}{ thermoneutral } & Tetra H & 0.42 & cde & 911 & abcdefghi & 0.69 & cdefghij & 1.71 & ghi & 26.38 & ghijk \\
\hline & & $\begin{array}{l}\text { Tetra } \\
\text { Super } \\
\text { Harco }\end{array}$ & 0.364 & cde & 829 & bcdefghi & 0.46 & fghij & 1.75 & fghi & 13.50 & I \\
\hline & & $\begin{array}{l}\text { White } \\
\text { Plymouth } \\
\text { rock }\end{array}$ & 0.360 & cde & 1282 & a & 0.63 & cdefghij & 1.84 & efghi & 23.34 & $\mathrm{ijkl}$ \\
\hline & & $\begin{array}{l}\text { Barred } \\
\text { Plymouth } \\
\text { rock }\end{array}$ & 0.258 & cde & 1097 & $a b c d$ & 0.33 & ghij & 1.83 & efghi & 20.63 & $\mathrm{jkl}$ \\
\hline & & Bielefelder & 0.268 & cde & 1029 & abcdefg & 0.52 & efghij & 2.14 & efghi & 31.54 & defghij \\
\hline & & Australorp & 0.320 & cde & 1158 & $a b c$ & 0.66 & cdefghij & 2.19 & efghi & 35.47 & cdefghi \\
\hline & & $\mathrm{m} \pm$ SEM & \multicolumn{2}{|c|}{$0.33 \pm 0.03$} & \multicolumn{2}{|c|}{$1051 \pm 67$} & \multicolumn{2}{|c|}{$0.55 \pm 0.06$} & \multicolumn{2}{|c|}{$1.91 \pm 0.08$} & \multicolumn{2}{|c|}{$25.14 \pm 3.2$} \\
\hline & \multirow[t]{6}{*}{ hot } & Tetra H & 1.900 & $a b$ & 1046 & abcdef & 0.97 & bcde & 3.84 & bcde & 41.36 & abcd \\
\hline & & $\begin{array}{l}\text { Tetra } \\
\text { Super } \\
\text { Harco }\end{array}$ & 1.181 & abcde & 831 & abcdefghi & 1.08 & $a b c$ & 3.26 & cdef & 25.18 & hijkl \\
\hline & & $\begin{array}{l}\text { White } \\
\text { Plymouth } \\
\text { Rock }\end{array}$ & 1.537 & $a b$ & 706 & cdefghi & 0.67 & cdefghij & 2.75 & defghi & 29.13 & efghij \\
\hline & & $\begin{array}{l}\text { Barred } \\
\text { Plymouth } \\
\text { Rock }\end{array}$ & 1.540 & $a b$ & 811 & bcdefghi & 0.79 & cdefg & 2.68 & defghi & 30.35 & defghij \\
\hline & & Bielefelder & 1.040 & abcde & 696 & defghi & 0.41 & ghij & 3.11 & defghi & 33.05 & cdefghij \\
\hline & & Australorp & 0.864 & bcde & 980 & abcdegh & 0.95 & bcdef & 2.64 & defghi & 32.44 & cdefghij \\
\hline \multicolumn{13}{|c|}{ *Note: Values with different letters are significantly different according to ANOVA and Tukey's multiple range test. } \\
\hline & & ore forehea & & $n$ the & habe & nen the & & ling inc & & & & \\
\hline
\end{tabular}




\begin{tabular}{|c|c|c|c|c|c|}
\hline Factors & \multicolumn{5}{|c|}{ Biochemical indicators of oxidative stress } \\
\hline $\mathrm{m} \pm \mathrm{SEM}$ & $1.34 \pm 0.16$ & $845 \pm 58$ & $0.81 \pm 0.09$ & $3.05 \pm 0.19$ & $31.92 \pm 2.21$ \\
\hline $\mathrm{m} \pm \mathrm{SEM}$ (for I and II years) & $0.98 \pm 0.10$ & $844 \pm 33$ & $0.62 \pm 0.05$ & $2.65 \pm 0.16$ & $33.09 \pm 1.32$ \\
\hline \multicolumn{6}{|c|}{ *Note: Values with different letters are significantly different according to ANOVA and Tukey's multiple range test. } \\
\hline
\end{tabular}

It was found that the lowest values of LPO were present in the hens during the thermoneutral period for both years. The lowest $\mathrm{LPO}$ value $(0.16 \mathrm{nmoles} \mathrm{MDA} / \mathrm{mg} \mathrm{Hb})$ was observed in the Australorp breed during the thermoneutral period in the $1 \mathrm{st}$ year. It should be noted that in this genotype the LPO was low, regardless of the period. Both the cold and hot periods appeared to be unfavorable with elevated LPO in all genotypes. The highest LPO values were recorded for the Tetra Super Harco during the cold period of the 2nd year (1.98 nmoles MDA/mg Hb) and also for Barred Plymouth Rock (1.91 nmoles MDA/mg Hb) and White Plymouth Rock (1.91 nmoles MDA/mg Hb) during the hot period of the 1st year. Specific variations in response to the rearing conditions were also manifested by the tGSH concentrations in the erythrocyte suspension. Significantly lower tGSH levels were observed in the hens during the cold period compared to the thermoneutral and hot periods. The highest value was recorded during the thermoneutral period of the $2 \mathrm{nd}$ year for Withe Plymouth Rock (1282 ng/mg Hb) and the lowest was found in the Australorp breed during the cold period of the 1 st year $(490 \mathrm{ng} / \mathrm{mg} \mathrm{Hb})$.

Variations in the antioxidant enzyme system in relation to the rearing conditions were also well demonstrated. CAT activity for all genotypes tested was lower during the cold periods and higher during the hot periods in comparison to the thermoneutral periods of both year replicates. The highest value was recorded in Tetra Super Harco during the hot period of the 1st year (1.54 U/mg Hb) and the lowest in Barred Plymouth Rock during the cold period of the same year $(0.23 \mathrm{U} / \mathrm{mg} \mathrm{Hb})$. The estimated SOD activities were higher both in the cold and the hot periods indicating that low and high temperatures lead to activation of the enzyme with a more expressed increase during the hot period. The maximum SOD value (5.51 U/mg Hb) was observed for Tetra $\mathrm{H}$ during the hot period of the $1 \mathrm{st}$ year, followed by Tetra Super Harco for the same period $(4.87 \mathrm{U} / \mathrm{mg} \mathrm{Hb})$. The analysis of the changes in GPX activity showed the same tendency as for SOD. In comparison to the thermoneutral period, an increase of the enzyme activity was observed during the cold and hot periods of both years in all hens' genotypes except for Bielefelder and Australorp breeds during the hot period. Tetra Super Harco had the lowest enzyme activity with values of $16.75 \mathrm{U} / \mathrm{mg} \mathrm{Hb}$ and $13.50 \mathrm{U} / \mathrm{mg}$ $\mathrm{Hb}$ during the thermoneutral period in the 1 st and 2nd year, correspondingly.

A correlation analysis was performed to determine the degree of correlation between the individual indicators. The calculated phenotypic correlation coefficients are presented in Table 3. The only unproven relationship is between SOD and tGSH. Between all other indicators, significant phenotypic correlations are reported. The increase in LPO has a slight and negative impact on tGSH $\left(R=-0.262^{\star *}\right)$ and low to moderate positive impact on CAT $\left(R=0.228^{\star *}\right)$, SOD $\left(R=0.402^{\star \star}\right)$ and GPX $\left(R=0.200^{\star \star}\right)$. The phenotypic correlation between tGSH and CAT is weakly positive $\left(R=0.224^{* *}\right)$ and negative between tGSH and GPX $(R=$ $-0.169 *)$. Increases in CAT values have a moderately positive effect on the change in SOD $\left(R=0.477^{\star *}\right)$ and weak effect on that of GPX $\left(R=0.155^{\star}\right)$. There is also a low phenotypic correlation between SOD and GPX $\left(R=0.164^{\star}\right)$. 
Table 3

Phenotypic correlations between oxidative stress markers

\begin{tabular}{|llllll|}
\hline Indicator & LPO & tGSH & CAT & SOD & GPX \\
\hline LPO & - & $-0.262^{\star \star}$ & $0.228^{\star *}$ & $0.402^{\star \star}$ & $0.200^{\star \star}$ \\
\hline tGSH & - & $0.224^{\star *}$ & -0.02 n.s. & $-0.169^{\star}$ \\
\hline CAT & & & - & $0.477^{\star \star}$ & $0.155^{\star}$ \\
\hline SOD & & & - & $0.164^{\star}$ \\
\hline GPX & & & & - \\
\hline Note: Significance at *: $\mathrm{P}<0.05 ; * *$ : $\mathrm{P}<0.01$; n.s. - no significant difference. \\
\hline
\end{tabular}

In an attempt to assess the overall effects of the changing rearing condition factors (year, period and genotype) on the biochemical indicators of OS (LPO, tGSH, CAT, SOD, GPX) a factorial ANOVA was carried out (Table 4). All studied factors proved to have statistically significant main effects on the OS indicators, except for the factor "year" on LPO and "genotype" on tGSH. In addition, all interactions of the studied factors proved to have significant effects.

Table 4

Factorial analysis of variance of the effects of the investigated factors (year, period, genotype) on the oxidative stress markers

\begin{tabular}{|c|c|c|c|c|c|c|}
\hline \multirow[t]{2}{*}{ Factors } & & \multicolumn{5}{|c|}{ Source of variance } \\
\hline & & LPO & $\mathrm{tGSH}$ & CAT & SOD & GPX \\
\hline \multirow[t]{2}{*}{ Year } & $\mathrm{F}$ & 1.369 & 5.622 & 3.770 & 12.401 & 21.346 \\
\hline & probability & n.s. & $P<0.05$ & $P<0.05$ & $P<0.001$ & $P<0.001$ \\
\hline \multirow[t]{2}{*}{ Period } & $\mathrm{F}$ & 81.285 & 22.343 & 65.846 & 59.648 & 9.889 \\
\hline & probability & $P<0.001$ & $P<0.001$ & $P<0.001$ & $P<0.001$ & $P<0.001$ \\
\hline \multirow[t]{2}{*}{ Genotype } & $\mathrm{F}$ & 5.002 & 1.754 & 5.280 & 3.522 & 9.744 \\
\hline & probability & $P<0.01$ & n.s. & $P<0.001$ & $P<0.01$ & $P<0.001$ \\
\hline \multirow[t]{2}{*}{ Year $_{\mathrm{x}}$ Period } & $\mathrm{F}$ & 32.408 & 16.326 & 30.651 & 32.605 & 8.585 \\
\hline & probability & $P<0.001$ & $P<0.001$ & $P<0.001$ & $P<0.001$ & $P<0.001$ \\
\hline \multirow[t]{2}{*}{ Year x Genotype } & $\mathrm{F}$ & 2.783 & 2.296 & 3.400 & 3.367 & 8.407 \\
\hline & probability & $P<0.05$ & $P<0.05$ & $P<0.001$ & $P<0.001$ & $P<0.001$ \\
\hline \multirow[t]{2}{*}{ Period $x$ Genotype } & $\mathrm{F}$ & 20.602 & 5.128 & 21.273 & 13.303 & 8.792 \\
\hline & probability & $P<0.001$ & $P<0.001$ & $P<0.001$ & $P<0.001$ & $P<0.001$ \\
\hline \multirow[t]{2}{*}{ Year $_{x}$ Period $x$ Genotype } & $\mathrm{F}$ & 10.812 & 5.970 & 14.341 & 10.193 & 7.49 \\
\hline & probability & $P<0.001$ & $P<0.001$ & $P<0.001$ & $P<0.001$ & $P<0.001$ \\
\hline
\end{tabular}

The statistically significant effects of the "year" (both main effects and interactions with the other factors) on the variation of OS markers confirmed that the factors of the rearing environment (i.e. primarily the seasonal temperature variation) were different in the two years replicates, although the experimental design was the same.

The studied chicken genotypes are significantly different in terms of egg productivity (Fig. 2 and Fif. 3). The Bielefelder breed seemed to be the most susceptible to high temperature, as in the first year its production in June was less than $30 \%$ (twice less 
than of the hens from the other genotypes). In general, in both year replicates, the hens belonging to the Tetra Super Harco had the highest egg production (63.28\% during the 1 st year and $74.93 \%$ during the 2 nd year). In the 1 st year, the second highest egg production belonged to the Australorp breed (58.89\%) and to the two chicken genotypes from the national Genetic Fund of Bulgaria - Barred Plymouth Rock - line E (57.69\%) and White Plymouth Rock - line G (54.18\%). In the 2nd year with the third highest egg production was the Barred Plymouth Rock breed (64.96\%) after White Plymouth Rock (67.18\%) and Tetra Super Harco (74.93). The Bielefelder breed was the lowest egg production in both years $-37.87 \%$ and $51.93 \%$ respectively.

\section{Discussion}

The main aim of the present research was to investigate experimentally the effects of seasonal variations in the rearing conditions in a free-range system on the pro/antioxidant balance in six genotypes of chickens, as defined by levels of the markers LPO, tGSH, CAT, SOD and GPX in blood erythrocytes. The effect of the oxidative status on the performance of the studied hen's genotypes was also assessed.

Dual-purpose chickens are preferred for family organic farming because they are both excellent layers and good meat producers. Although free-range rearing has a number of acknowledged advantages (Henry 2002), there are also a number of occurring unfavourable circumstances or conditions (Lin et al. 2006; Fossum et al. 2009; Lambton et al. 2015; Singh et al. 2017; Wuthijaree et al. 2017) that can affect the pro-antioxidant balance in chickens (Altan et al. 2003; Lin et al. 2006; Akşit et al. 2008; Rehman et al. 2018; Mishra and Jha 2019). Accordingly, the wellness of birds is related to their performance and in recent years a number of studies reported the effects of poultry rearing systems on egg production and quality, as well as on their OS status (Küçükyilmaz et al. 2012; Surai et al. 2017).

Results of the present study clearly showed that the blood pro/antioxidant balance of the laying hens' genotypes was affected by changes in the environmental factors of the rearing period, in particular seasonal temperature changes. Our results demonstrated variability in the values of different markers in response to the temperature period and the genotype. The comparative analysis showed that in the samples taken during both the cold and hot periods, a three to six-fold increase in erythrocyte LPO levels was observed in all genotypes in comparison to the thermoneutral period. The effects of the seasonal changes of the rearing temperatures in the two year replicates and the genotype on the OS markers were statistically significant both as main effects and also as interactive effects (Table 3). These results are consistent with the findings of other authors reporting similar effects in chickens' organs and tissues in controlled trials and reared in free environmental conditions with low (Akşit et al. 2008; Zhao et al. 2014) and high (Wang et al. 2009; Azad et al. 2010) temperatures. Specifically, in our study during the cold rearing conditions the highest level of the pro-oxidant marker LPO was induced in Tetra Super Harco hens in comparison to the other groups, whereas the Bielefelder breed had the lowest LPO values measured. Thus, this genotype appears to be cold resistant. The least affected by the heat impact in regard to LPO induction were the hens belonging to the Australorp breed. The observed increase in LPO during the cold period compared to the thermoneutral one was accompanied by a decrease in the tGSH level in the erythrocyte suspension of all tested genotypes. Reduced glutathione is an essential part of the body's antioxidant defence system being major cellular non-enzymatic antioxidant and a limiting co-substrate of the antioxidant enzyme GPX. Only in its presence GPX catalyzes the reduction of $\mathrm{H}_{2} \mathrm{O}_{2}$ or organic peroxides (Brigelius-Flohé and Maiorino 2013). Plasma and erythrocyte levels of tGSH are one of the main indicators of oxidative-reductive processes in the body. Its depletion in the birds is associated with the development of OS (Gradinski-Vrbanac et al. 2002). As regards the antioxidant enzymes assessed in this study, an increase in the erythrocyte SOD and GPX activity during the cold and hot periods compared to the thermoneutral period was observed. Similar activation of antioxidant enzymes has been described for chicken birds by many authors (Ramnath et al. 2008; Ramnath and Rekha 2009; Zhao et al. 2014). The activation of antioxidant enzymes is an adaptive response, aiming to protect cells from excess ROS generation, induced by the unfavourable environmental conditions (Surai 2016). The CAT activities showed a decrease during the cold periods and increase during the hot periods in both years. These variations in the antioxidant enzyme responses are not surprising since the exposure to acute or prolonged unfavourable conditions can lead to the enzymes inhibition. This is explained by the fact that antioxidant enzymes usually exhibit a "bell-shaped" response to increasing severity or exposure time of the pro-oxidant effects (Marigómez et al. 2013). Thus, it can be assumed that the observed low values of LPO in the Australorp breed are really caused by the observed relatively high activities of the antioxidant enzymes - SOD, CAT and GPX. 
A significant research question concerned the presence of relationships between the OS levels and the egg production of different hen's genotypes, reared under free-range rearing systems. Previous studies have shown the presence of a reverse relation between the level of LPO, as a pro-oxidative marker, and egg production (Kucuk et al. 2003). However, in our study significant direct correlation between LPO and egg productivity was not found. Taking into account the complex interactions among pro/antioxidant processes in determining OS levels, we applied factorial analysis of variance in an attempt to study possible relation of the OS status and egg production. The analysis proved the presence of significant interdependence between the oxidative status of the laying hens and their performance. This was true for all the studied hen's genotypes. However, the assessed OS markers had not only statistically significant main effects, but also participated in significant interactive effects. In particular, LPO had no statistically significant direct correlation with egg production, but participated in a number of significant interactive double and triple effects with the antioxidant enzymes (Table 4). These results strongly indicated that the intensity of the enzymatic antioxidant defence can have a significant effect on egg production. It is considered that the antioxidant enzymes SOD, CAT and GPX form the first line of defence of the organism against the damaging effect of the ROS (Ighodaro and Akinloye 2018; Surai et al. 2019). This undoubtedly suggests that the induction of pro-oxidative effects by factors associated with the rearing conditions can be specifically compensated by the cell antioxidant system and the degree of this compensation obviously determined the observed significant relations with the egg production of the studied genotypes. ROS trigger the redoxsignalling pathways with induction of transcription factors (NF-kB, Nrf2) and specific gene expression with antioxidant response element (ARE)-related synthesis of antioxidant enzymes (SOD, CAT, GPX, glutathione reductase, and glutathione transferase). This regulatory mechanism is considered to be fundamental for the effective antioxidant defence in stress conditions (Surai et al. 2017). Therefore, it is not surprising that the activity of antioxidant enzymes is important for the cell welfare and consequently for the normal run of the physiological processes in the organism. Hence, the contribution of both enzyme and non-enzymatic antioxidants for suppression of OS and sustaining the well-being of birds should not be neglected. This is in line with a number of studies which have showed that prevention of OS by supplementation with different antioxidants could improve bird status, performance and egg quality under stress conditions induced by low (Kucuk et al. 2003) and high (Abd El-Hack et al. 2017; Lin et al. 2002) ambient temperature. Indeed, the enzyme and non-enzyme antioxidants are proven to work in cooperation to overcome OS and cell injuries, thus facilitating the adaptation to various stresses in avian species (Surai et al. 2017, 2019).

In conclusion, this study reports for the first time results from detailed experimental research of the oxidative status and its effect on the egg-laying ability of six chicken genotypes reared in a free-range system for 3 periods in two consecutive years. Our data strongly indicated that naturally changing conditions in free-range rearing systems can shift the pro/antioxidant balance of the laying hens thus raising the risk of OS. This was especially well demonstrated in the response to temperature changes. The chicken genotypes we studied showed differences in their susceptibility/resistance to OS and this had an effect on their egg production. Generally, our results clearly demonstrated that induced OS is genotypically specific and can play a significant role in determining chicken welfare and egg production in free-range and similar breeding systems. Hence, the high performance of birds in free farming systems would strongly depend on using both highly productive and well adapted to local ambient conditions genotypes.

\section{Declarations}

\section{Funding}

The authors acknowledge the financial support of the University Science Fund at Agricultural University of Plovdiv, Grant № 1618.

\section{Competing interest}

The authors declare that they have no conflict of interest.

\section{Data availability}

All data generated and analysed during this study are included in this article.

\section{Author's contribution}

Page $12 / 17$ 
V. Gerzilov, V. Boncheva, and P. Petrov - conceiving and designing the experiment, acquisition of the fnancial support, experimental study with laying hens and egg production, collection and analyzing meteorological data.

A. Alexandrova, E. Tsvetanova and A. Georgieva - blood samples collection, biochemical analysis.

N. Keranova and V. Gerzilov - performing the statistical analysis.

V. Gerzilov and A. Alexandrova - validation, writing-reviewing and editing.

All authors read and approved the final manuscript.

\section{Ethics approval}

All applicable international and national guidelines for the care and welfare in poultry rearing, as well as animal ethics guidelines in the Agricultural University of Plovdiv, were followed. The blood samples were collected according to the rules of the Ethics Committee of the Institute of Neurobiology, Bulgarian Academy of Sciences.

\section{Consent to participate}

Not applicable.

\section{Consent for publication}

All authors give consent for publication.

\section{References}

1. Abd El-Hack ME, Mahrose K, Arif M, Chaudhry MT, Saadeldin IM, Saeed M, Soomro RN, Abbasi IHR, Rehman ZU. Alleviating the environmental heat burden on laying hens by feeding on diets enriched with certain antioxidants (vitamin $\mathrm{E}$ and selenium) individually or combined. Environ Sci Pollut Res. 2017; 24(11):10708-10717. https://doi:10.1007/s11356-0178690-5

2. Akşit M, Altan Ö, Karul AB, Balkaya M, Özdemir D. Effects of cold temperature and vitamin E supplementation on oxidative stress, troponin-T level, and other ascites related traits in broilers. Arch Geflügelkd. 2008; 72(5):221-230. ISSN 0003-9098.

3. Alexandrov V, Eitzinger J, Cajic V. Oberforster M. Potential impact of climate change on selected agricultural crops in northeastern Austria. Global Change Biol. 2002; 8(4):372-389. https://doi:10.1046/j.1354-1013.2002.00484.x

4. Altan ÖZGE, Pabuçcuoğlu A, Altan A., Konyalioğlu S, Bayraktar H. Effect of heat stress on oxidative stress, lipid peroxidation and some stress indicators in broilers. Brit Poult Sci. 2003; 44(4):545-550. https://oi:10.1080/00071660310001618334

5. Appleby MC, Hughes BO. Welfare of laying hens in cages and alternative systems: environmental, physical and behavioural aspects. World Poult Sci J. 1991; 47(2):109-128. https://doi.org/10.1079/WPS19910013

6. Azad MA, Kikusato M, Maekawa T, Shirakawa H, Toyomizu M. Metabolic characteristics and oxidative damage to skeletal muscle in broiler chickens exposed to chronic heat stress. Comp Biochem Phys A. 2010; 155(3):401-406. https://doi:10.1016/j.cbpa.2009.12.011

7. Brigelius-Flohé R, Maiorino M. Glutathione peroxidases. Biochim Biophys Acta. 2013; 1830(5):3289-3303. https://doi:10.1016/j.bbagen.2012.11.020

8. EU Council Directive 1999/74/EC of 19 July 1999. Laying down minimum standards for the protection of laying hens. Official Journal of the European Communities 1999 L 203/53-57 http://data.europa.eu/eli/dir/1999/74/oj. Accessed 15 October 2021

9. Fossum O, Jansson DS, Etterlin PE, Vågsholm I. Causes of Mortality in Laying Hens in Different Housing Systems in 2001 to 2004. Acta Vet Scand. 2009; 51(1):1-9. https://doi:10.1186/1751-0147-51-3

10. Gradinski-Vrbanac B, Stojević Z, Milinković-Tur S, Balenović T, Piršljin J, Zdelar-Tuk M. In vitro susceptibility of duck, chicken, and pig erythrocyte lipids to peroxidation. Vet Med - Praha. 2002; 47(10/11):303-308. https://doi:10.17221/5839-VETMED 
11. Henry R. Organic poultry - eggs. Maritime Certified Organic Growers - Organic Profiles, March 2002.

12. Hilton P, McMurray I. Presenting your data with SPSS explained. Taylor \& Francis, New York, 2014. https://doi.org/10.4324/9781315689524

13. Ighodaro OM, Akinloye, OA. First line defence antioxidants-superoxide dismutase (SOD), catalase (CAT) and glutathione peroxidase (GPX): their fundamental role in the entire antioxidant defence grid. Alexandria J Med. 2018; 54(4):287-293. https://doi:10.1016/j.ajme.2017.09.001

14. Kucuk O, Sahin N, Sahin K, Gursu MF, Gulcu F, Ozcelik M, Issi M. Egg production, egg quality, and lipid peroxidation status in laying hens maintained at a low ambient temperature $\left(6^{\circ} \mathrm{C}\right)$ and fed a vitamin $\mathrm{C}$ and vitamin E-supplemented diet. Vet Med Praha. 2003; 48(12):33-40. https://doi.org/10.17221/5747-VETMED

15. Küçükyılmaz K, Bozkurt M, Herken E, Cınar M, Catlı AU, Bintaş E, Cöven F. Effects of rearing systems on performance, egg characteristics and immune response in two layer hen genotype. Asian Austral J Anim. 2012; 25(4):559-568.

https://doi:10.5713/ajas.2011.11382

16. Lamarca DSF, Pereira DF, Magalhães MM, Salgado DD. Climate change in layer poultry farming: impact of heat waves in region of bastos. Braz J Poult Sci. 2018; 20(4):657-664. https://doi:10.1590/1806-9061-2018-0750

17. Lambton SL, Knowles TG, Yorke C, Nicol CJ. The risk factors affecting the development of vent pecking and cannibalism in free-range and organic laying hens. Anim Welfare. 2015; 24(1):101-111. https://doi:10.7120/09627286.24.1.101

18. Lin H, Decuypere E, Buyse J. Acute heate stress induces oxidative stress in broiler chicken. Comp Biochem Phys A. 2006; 144(1):11-17. https://doi:10.1016/j.cbpa.2006.01.032

19. Lin H, Wang LF, Song JL, Xie YM, Yang QM. Effect of dietary supplemental levels of vitamin A on the egg production and immune responses of heat-stressed laying hens. Poult Sci. 2002; 81(4):458-465. https://doi:10.1093/ps/81.4.458

20. Mack LA, Felver-Gant JN, Dennis RL, Cheng HW. Genetic variation alter production and behavioral responses following heat stress in 2 strains of laying hens. Poult Sci. 2013; 92(2):285-294. https://doi:10.3382/ps.2012-02589

21. Marigómez I, Garmendia L, Soto M, Orbea A, Izagirre U, Cajaraville MP. Marine ecosystem health status assessment through integrative biomarker indices: a comparative study after the prestige oil spill "Mussel Watch". Ecotoxicology. 2013;

22(3):486-505. https://doi:10.1007/s10646-013-1042-4

22. Meyers L, Gamst G, Guarino A. Performing Data Analysis Using IBM SPSS. Wiley, New York, 2013. https://www.wiley.com/en-us/Performing+Data+Analysis+Using+IBM+SPSS-p-9781118357019

23. Ming $X$, Xian-yi Y, Jin-long L, Yan-hui H, Shu L, Shi-wen X. Effects of acute and chronic cold stress on antioxidant function in intestinal tracts of chickens. J Northeast Agric Univ (Eng Ed). 2012; 19(2):54-61. https://doi:10.1016/S10068104(13)60038-0

24. Mishra B, Jha R. Oxidative Stress in the Poultry Gut: Potential Challenges and Interventions. Front Vet Sci. 2019; 6:60. https://doi:10.3389/fvets.2019.00060

25. Rahman I, Kode A, Biswas SK. Assay for quantitative determination of glutathione and glutathione disulfide levels using enzymatic recycling method. Nat Protoc. 2006; 1(6):3159-3165. https://doi:10.1038/nprot.2006.378

26. Ramnath V, Rekha PS. Brahma rasayana enhances in vivo antioxidant status in cold-stressed chickens (Gallus Gallus Domesticus). Indian J Pharmacol. 2009; 41(3):115-119. https://doi:10.4103/0253-7613.55209

27. Ramnath V, Rekha PS, Sujatha KS. Amelioration of heat stress induced disturbances of antioxidant defense system in chicken by Brahma rasayana. eCAM. 2008; 5(1):77-84. https://doi:10.1093/ecam/nel116

28. Rehman ZU, Meng C, Sun Y, Safdar A, Pasha RH, Munir M, Ding C. Oxidative stress in poultry: Lessons from the viral infections. Oxid Med Cell Longev. 2018, ID 5123147. https://doi:10.1155/2018/5123147

29. Rhoads RP, Baumgard LH, Suagee JK, Sanders SR. Nutritional interventions to alleviate the negative consequences of heat stress. Adv Nutr. 2013; 4(3):267-276. https://doi:10.3945/an.112.003376

30. Selye H. Stress without distress. In: Serban G (ed). Psychopathology of Human Adaptation. Springer, Boston, MA, USA, 1976; 137-146.

31. Sies H. Oxidative Stress: Introductory Remarks. In: Sies H (ed), Oxidative Stress. Academic Press, London, UK, 1985; 1-8. 
32. Singh M, Ruhnke I, de Koning C, Drake K, Skerman AG, Hinch GN, Glatz PC. Demographics and practices of semi-intensive free-range farming systems in australia with an outdoor stocking density of $\leq 1500$ hens/hectare. PLoS One. 2017; 12(10), e0187057. https://doi.org/10.1371/journal.pone.0187057

33. Surai P. Antioxidant systems in poultry biology: Superoxide dismutase. J Anim Res Nutr. 2016; 1(1):8. https://doi:10.21767/2572-5459.100008.

34. Surai P, Kochish I, Fisinin V. Antioxidant systems in poultry biology: Nutritional modulation of vitagenes. Eur Poult Sci. 2017; 81, ISSN 1612-9199. https://doi:10.1399/eps.2017.214

35. Surai P, Kochish I, Fisinin V, Kidd MT. Antioxidant defence systems and oxidative stress in poultry biology: an update. Antioxidants (Basel). 2019; 8(7):235. https://doi:10.3390/antiox8070235

36. Vandana GD, Sejian V, Lees AM, Pragna P, Silpa MV, Maloney SK. Heat stress and poultry production: impact and amelioration. Int J Biometeorol. 2021; 65(2):163-179.

37. Wang RR, Pan XJ, Peng ZQ. Effects of heat exposure on muscle oxidation and protein functionalities of pectoralis major in broilers. Poult Sci. 2009; 88(5):1078-1084. https://doi:10.3382/ps.2008-00094

38. Wuthijaree K, Lambertz C, Gauly M. Prevalence of gastrointestinal helminth infections in free-range laying hens under mountain farming production conditions. Brit Poult Sci. 2017; 58(6):649-655.

https://doi.org/10.1080/00071668.2017.1379049

39. Zhao FQ, Zhang ZW, Qu JP, Li M, Li S, Xu SW. Cold stress induces antioxidants and hsps in chicken immune organs. Cell Stress and Chaperones. 2014; 19(5):635-648. https://doi.org/10.1007/s12192-013-0489-9

\section{Supplementary}

Supplementary material S2 is not available with this version

\section{Figures}
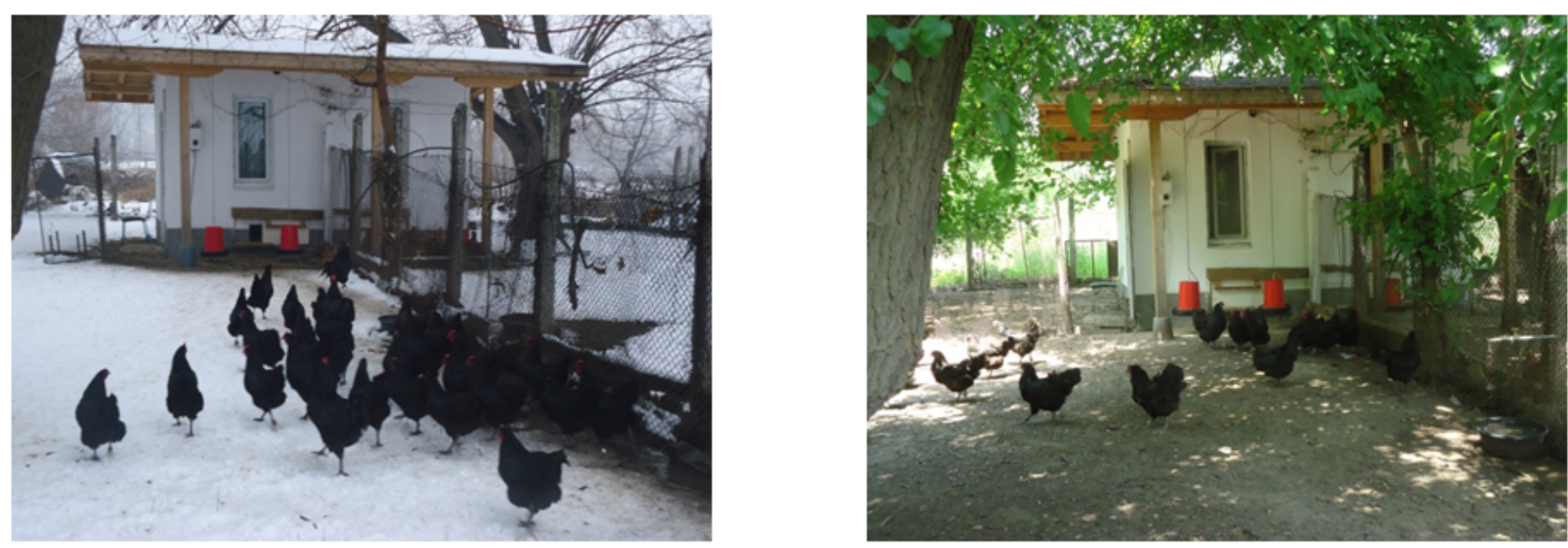

\section{Figure 1}

Rearing of poultry in the cold and hot period 

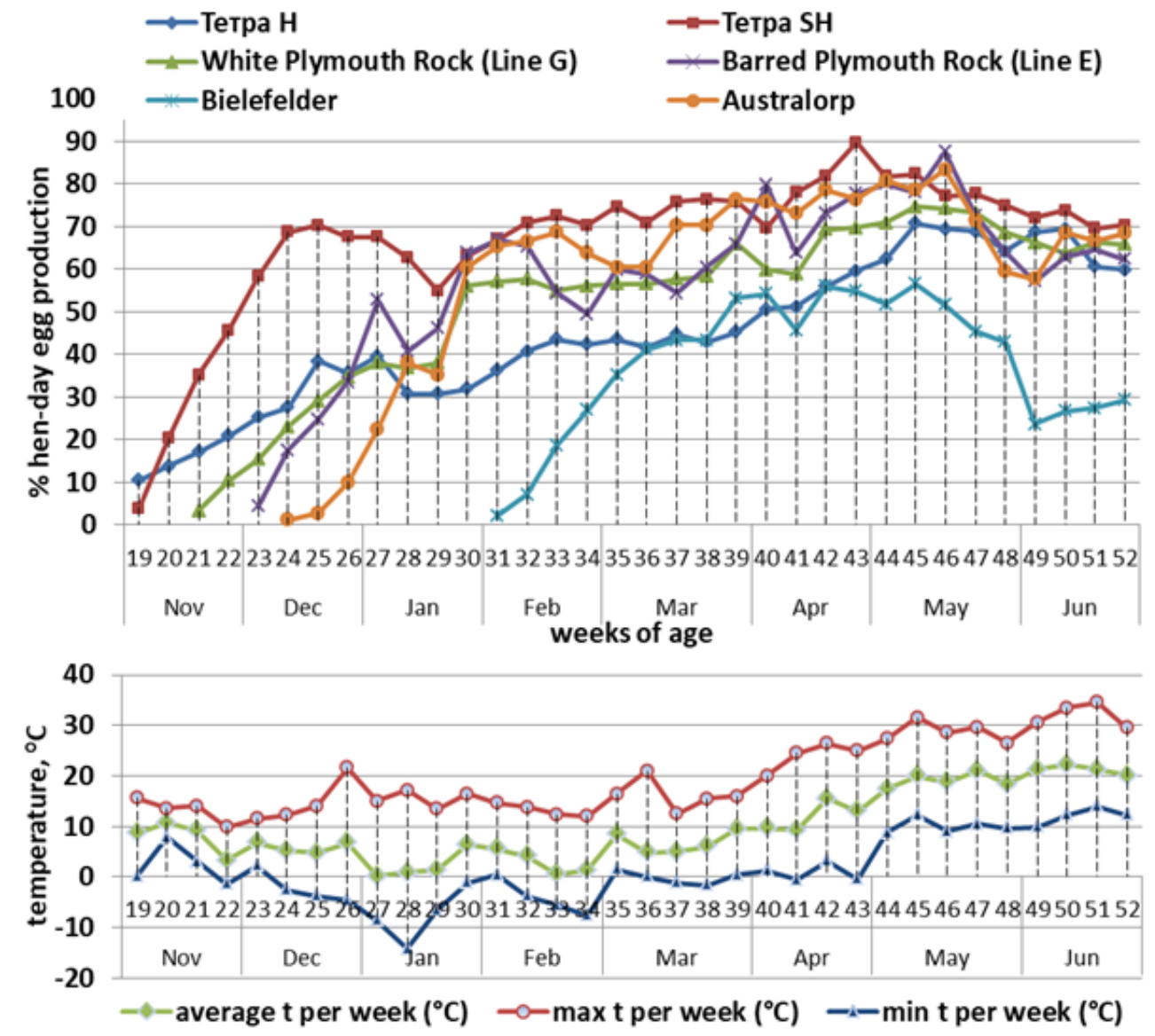

Figure 2

Egg laying performance $(\%)$ and ambient temperature $\left({ }^{\circ} \mathrm{C}\right)$ in first experimental year 

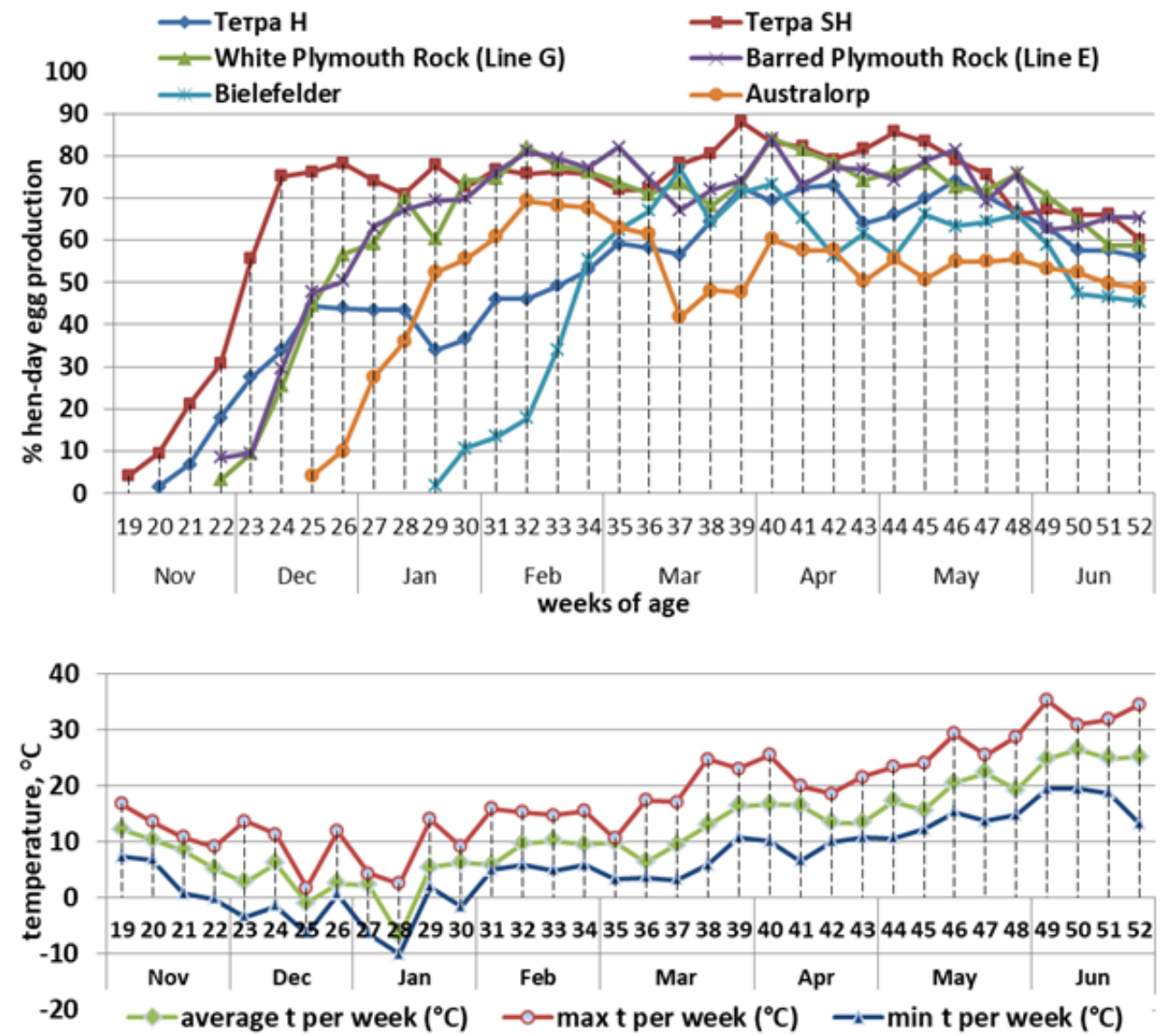

Figure 3

Egg laying performance $(\%)$ and ambient temperature $\left({ }^{\circ} \mathrm{C}\right)$ in second experimental year

\section{Supplementary Files}

This is a list of supplementary files associated with this preprint. Click to download.

- FIG2year1.xlsx

- FIG3year2.xlsx 